\title{
KONDISI DAN MANFAAT LANGSUNG EKOSISTEM HUTAN MANGROVE DESA PENUNGGUL KECAMATAN NGULING KABUPATEN PASURUAN
}

\author{
Achmad Sofian $^{1)}$, Nuddin Harahab ${ }^{2)}$, Marsoedi ${ }^{3)}$ \\ ${ }^{1)}$ Prodi Pengelolaan Sumberdaya, Lingkungan dan Pembangunan Universitas Brawijaya \\ ${ }^{2)}$ 3) Pascasarjana Universitas Brawiajaya \\ Email: asof_achmad@yahoo.com
}

\begin{abstract}
Abstrak
Hutan mangrove memiliki manfaat dan fungsi ekologi dan ekonomi yang sangat strategis bagi masyarakat. Tujuan dari penelitian ini adalah untuk mengetahui : 1) kondisi hutan mangrove Desa Penunggul dan 2)manfaat langsung dari ekosistem hutan mangrove Desa Penunggul Penelitian ini dilaksanakan pada bulan Dessember 2011- Januari 2012. Pengumpulan data diperoleh dari pengamatan langsung, wawancara dengan masyarakat dan pemerintah desa dan studi pustaka. Berdasarkan hasil penelitian hutan mangrove Desa Penunggul merupakan hutan hasil penanaman dan bukti keberhasilan upaya penyelamatan lingkungan pantai oleh masyarakat. Terdapat dua jenis mangrove yaitu Rhizophora sp and Avicennia sp. Rhizophora sp mendominasi ekosistem mangrove di Desa Penunggul. Manfaat langsung ekosistem hutan mangrove terdiri dari bibit mangrove, perikanan (kerang, kepiting dan rajungan), dan pendidikan dan pariwisata.
\end{abstract}

Kata kunci : kondisi, ekosistem mangrove, manfaat langsung, Penunggul

\section{Pendahuluan}

Hutan mangrove merupakan ekosistem khas di wilayah pesisir dan dipengaruhi pasang surut air laut. Bagi masyarakat pesisir khususnya, hutan mangrove disadari atau tidak, mempunyai fungsi sangat strategis secara ekologi, sosial, maupun ekonomi dalam kehidupannya. Hutan mangrove memiliki banyak fungsi, selain manfaat yang langsung secara nyata dirasakan oleh masyarakat dan bahkan menjadi sumber penghidupan ekonomi seperti kayu dan pohon, ikan, kepiting,dan lain sebagainya juga manfaat tidak langsung penahan abrasi dan tempat ikan bertelur dan memijah. Namun, seiring dengan meningkatnya aktivitas masyarakat di wilayah pesisir dan kebutuhan yang diingini yang tinggi menyebabkan hutan mangrove mengalami tekanan yang dapat mengancam keberadaan dan fungsinya. Kondisi tersebut pada akhirnya dapat merugikan manusia dan alam karena terkait dengan berkurangnya fungsi-fungsi baik ekologis maupun ekonomi dan fungsi lainnya.

Kerusakan lingkungan yang terjadi baik pada ekosistem laut maupun ekosistem lainnya memang banyak dipicu oleh berbagai faktor. Namun, secara umum dua pemicu yang cukup dominan adalah kebutuhan ekonomi (economic driven) dan kegagalan kebijakan (policy failure driven) (Fauzi, 2005). Manusia memiliki tugas mulia dalam mengelola sumberdaya alam dan lingkungan supaya tetap lestari dan berkelanjutan. Menurut Al Qardhawi (2001) menjaga sumber kekayaan alam yang notabene merupakan nikmat Allah swt bagi makhlukNya, adalah kewajiban bagi setiap manusia. Barangsiapa yang hendak mensyukuri nikmat tersebut, harus selalu menjaganya dari pencemaran, kehancuran, serta bentuk-bentuk lain yang termasuk dalam kategori perusakan diatas muka bumi.

Indonesia memiliki hutan bakau terluas di Asia Tenggara, yakni 7,7 juta hektar. Akan tetapi, pertumbuhan pemukiman, aktivitas ekonomi, dan eksploitasi kayu bakau berlebihan untuk dijadikan arang menyebabkan hutan bakau tersisa 3,6 juta hektar (Kompas, 21 Desember 2011). Hutan mangrove di Indonesia merupakan yang terluas, sekitar $23 \%$ dari seluruh hutan mangrove dunia. Pada tahun 1982, luas hutan mangrove di Indonesia diperkirakan sekitar 4,25 juta ha, terutama terdapat di sepanjang pesisir pulau-pulau besar Indonesia. Pada tahun 1987, luas hutan mangrove tersebut telah berkurang dan hanya tersisa 3,24 juta ha, bahkan pada tahun 1995 dilaporkan bahwa hutan mangrove Indonesia hanya tersisa 2,06 juta ha, yang berarti berkurang seluas 1,18 juta ha (Rahman, 2008).

Kecamatan Nguling merupakan wilayah yang mengalami peningkatan luasan hutan mangrove di Kabupaten Pasuruan dari 3,5 Ha di 
tahun 1985 meningkat menjadi 84,6 Ha di tahun 2005 (Anonym, 2004 dalam Harahab, 2009). Dari data tersebut sebagian besar hutan mangrove berada di Desa Penunggul. Wilayah pesisir Desa Penunggul Kecamatan Nguling sebelumnya merupakan areal pertambakan hasil konversi kawasan mangrove dan jarang sekali ditumbuhi tanaman, bahkan terjadi abrasi yang tiap tahun semakin mendekati pemukiman. Namun, pesisir Kecamatan Nguling sekarang dipenuhi rimbunnya hutan mangrove terutama di Desa Penunggul.

Keberhasilan konservasi hutan mangrove di Kecamatan Nguling telah membawa manfaat yang cukup berarti bagi masyarakat sekitar hutan, yaitu meningkatnya jumlah produksi dan nelayan yang melakukan penangkapan ikan di sekitar ekosistem hutan mangrove dan terlindungnya wilayah pantai dari bahaya banjir dan angin badai (Harahab, 2009). Penanaman dan pelestarian hutan mangrove dilatarbelakangi adanya kepedulian masyarakat dengan tokohnya Pak Mukarim.

Penelitian ini bertujuan untuk : 1) mengetahui kondisi hutan mangrove Desa Penunggul; 2) jenis-jenis pemanfaatan langsung ekosistem hutan mangrove Desa Penunggul.

\section{Metode Penelitian}

Penelitian dilaksanakan pada bulan Desember 2011 sampai dengan Januari 2012 di hutan mangrove Desa Penunggul Kecamatan Nguling, Kabupaten Pasuruan, Provinsi Jawa Timur. Kondisi hutan mangrove diketahui dengan pengamatan secara langsung di lapangan dan mengkaji penelitian-penelitian sebelumnya.

Metode pengukuran yang digunakan untuk mengetahui kondisi mangrove adalah dengan menggunakan Metode Transek Garis dan Petak Contoh (Line Transect Plot). Plotplot berbentuk bujur sangkar berukuran $10 \times 10$ $\mathrm{m}$ untuk mengamati tingkat pohon (diameter $\geq$ $10 \mathrm{~cm}$ ), di dalam plot yang berukuran $10 \times 10 \mathrm{~m}$ tadi dibuat plot yang berukuran lebih kecil dengan ukuran $5 \times 5 \mathrm{~m}$ untuk pengamatan mangrove di tingkat pancang (diameter $<10$ $\mathrm{cm}$; tinggi $\geq 1,5 \mathrm{~m}$ ), di dalam plot berukuran $5 \mathrm{x}$ $5 \mathrm{~m}$ ini dibuat plot yang berukuran $2 \times 2 \mathrm{~m}$ untuk pengamatan mangrove pada tingkat semai (tinggi $<1,5 \mathrm{~m}$ ).

Pada setiap plot-plot tersebut, di identifikasi jenis vegetasi mangrove yang ada, jumlah individu setiap jenis pada setiap tingkatan vegetasi mangrove. Dari data tersebut dianalisis secara kuantitatif untuk mendapatkan beberapa parameter tumbuhan seperti: Kerapatan (K), Kerapatan Relatif (KR), Frekuensi, Frekuensi Relatif (FR), Dominansi (D), Dominansi Relatif (DR) dan Indeks Nilai Penting (INP).

Perhitungan besarnya nilai kuantitif parameter vegetasi, khususnya dalam penentuan indeks nilai penting, dilakukan dengan formula berikut ini (Onrizal, 2008):

a. Kerapatan suatu jenis (K) (ind/ha)

$$
K=\frac{\sum \text { individu suatu jenis }}{\text { Luas petak contoh }}
$$

b. Kerapatan relatif suatu jenis (KR) (\%)

$$
K R=\frac{K \text { suatu jenis }}{K \text { seluruh jenis }} \times 100 \%
$$

c. Frekuensi suatu jenis (F)

$$
F=\frac{\Sigma \text { sub-potak ditemukan suatu jonis }}{\sum \text { Seluruh sub-petak contoh }}
$$

d. Frekuensi relatif suatu jenis (FR) (\%)

$$
F R=\frac{F \text { suatu jenis }}{F \text { seluruh jenis }} \times 100 \%
$$

e. Dominansi suatu jenis (D) $\left(\mathrm{m}^{2} / \mathrm{ha}\right)$. D hanya dihitung untuk tingkat pohon.

$$
D=\frac{\text { Luas bidang dasar suatu jenis }}{\text { Luas petak contoh }}
$$

f. Dominansi relatif suatu jenis (DR) (\%)

$$
D R=\frac{D \text { suatu jenis }}{D \text { seluruh jenis }} \times 100 \%
$$

g. Indeks Nilai Penting (INP) (\%)

g.1. Untuk tingkat pohon adalah INP $=\mathrm{KR}+$ $\mathrm{FR}+\mathrm{DR}$

g.2. Untuk tingkat semai dan pancang adalah $\mathrm{INP}=\mathrm{KR}+\mathrm{FR}$

Menurut Snedakeer dan Snedaker (1984) dalam Suryawan (2007) indeks nilai penting (INP) merupakan besaran yang menunjukkan kedudukan suatu jenis terhadap jenis lain didalam suatu komunitas. INP diturunkan dari kerapatan relatif $(\mathrm{Kr})$, frekuensi relatif (Fr) dan dominansi relatif (Dr) dari jenisjenis yang menyusun komunitas yang diamati INP dikelompokkan dalam tiga katagori yaitu: tinggi, sedang dan rendah, dengan rumus berikut (Suryawan, 2007):

$I_{z}=\frac{I N P \text { terting gi dari jenis }}{3 \text { (kategori })}$

INP tinggi $(\mathrm{T}): \mathrm{T} \geq 2 \mathrm{I}_{\mathrm{z}}$

INP sedang $(\mathrm{S}): \mathrm{Iz}<\mathrm{S}<2 \mathrm{I}_{\mathrm{z}}$ INP rendah $(\mathrm{R}): \mathrm{R}<\mathrm{I}_{\mathrm{z}}$

Kegiatan untuk mengetahui pemanfaatan langsung ekosistem hutan mangrove meliputi observasi (pengamatan) lapangan, wawancara, serta kajian literatur kemudian dijelaskan secara dekriptif. 


\section{Hasil Dan Pembahasan}

\section{Kondisi Hutan Mangrove}

Hutan mangrove terbentuk karena adanya perlindungan dari ombak, masukan air tawar dari sungai, sedimentasi dan aliran air pasang surut (Goldman dan Horne, 1983 dalam Setyawan, et.al, 2002). Hutan mangrove Desa Penunggul didukung dengan kondisi terlindung dari ombak dengan adanya tanah timbul yang semakin menjorok ke laut dan rimbunnya hutan, mendapatkan masukan air tawar dari sungai Laweyan, sedimentasi yang tinggi ketika banjir lumpur dari hulu sungai dan pasang surut air laut setiap hari. Kondisi tersebut juga sesuai dengan penjelasan Gunarto (2004) bahwa mangrove biasanya berada di daerah muara sungai atau estuarin sehingga merupakan daerah tujuan akhir dari partikel-partikel organik ataupun endapan lumpur yang terbawa dari daerah hulu akibat adanya erosi. Dengan demikian, daerah mangrove merupakan daerah yang subur, baik daratannya maupun perairannya, karena selalu terjadi transportasi nutrien akibat adanya pasang surut.

Desa Penunggul memiliki cakupan pesisir pantai dengan luas hutan mangrove seluas 105 Ha (Mukarim, 2012). Hutan mangrove Desa Penunggul merupakan hutan mangrove hasil penanaman (reboisasi) dengan jenis mangrove yang mendominasi yaitu Rhizophora sp. Vegetasi mangrove menunjukkan peranan suatu jenis tanaman mangrove dalam ekosistem, keadaan tersebut ditunjukkan oleh indeks nilai penting. Indeks nilai penting (INP) diperoleh dari penjumlahan nilai kerapatan relative jenis, frekuensi relative jenis, dan penutupan relative jenis. Dari tiga unsur nilai tersebut, kondisi sempurna ditunjukkan dengan nilai 100 persen pada masing-masing unsur, hal ini umumnya tercapai pada wilayah hutan hasil reboisasi (Harahab, 2011).

Stasiun I berlokasi di Timur Desa Penunggul yakni berbatasan dengan Sungai Laweyan dan Desa Tambakrejo Kecamatan Tongas Kabupaten Probolinggo, sedangkan stasiun II berlokasi di bagian tengah dekat sarana wisata mangrove. Pada setiap zona hutan mangrove yang berada di sepanjang transek garis, diletakkan secara acak petak-petak contoh (plot) yang berbentuk bujur sangkar dan di dalam transek tersebut sebagai area untuk pengamatan. Jenis vegetasi mangrove yang ditemukan meliputi 2 famili, yaitu family
Avicenniaceae (Avecennia sp) dan Rhizophoraceae (Rhizophora sp). Keterbatasan jumlah jenis ini dikarenakan hutan mangrove Desa Penunggul merupakan hasil penanaman dengan jenis utama Rhizophora sp dan hingga kini penanaman tetap berlangsung dengan dukungan masyarakat, pemerintah dan pihak swasta. Luasnya hutan mangrove Desa Penunggul secara nyata dapat diamati dan dirasakan manfaatnya oleh masyarakat. Hal ini juga menunjukkan tingginya tingkat kepedulian masyarakat terhadap hutan mangrove.

Kondisi hutan mangrove yang berhadapan langsung dengan laut sehingga mendapatkan pasang surut air laut sangat mendukung kedua jenis tersebut untuk tumbuh. Vegetasi mangrove mempunyai morfologi dan anatomi tertentu sebagai respons fisiogenetik terhadap habitatnya. Vegetasi mangrove yang bersifat halopitik menyukai tanah-tanah yang bergaram, misalnya Avicennia sp., Bruguiera sp., Lumnitzera sp., Rhizophora sp., dan Xylocarpus sp. Vegetasi tersebut menentukan ciri lahan mangrove berdasarkan sebaran, dan sangat terikat pada habitat mangrove (Gunarto, 2004).

$\begin{array}{ccc}\text { Komposisi dan Struktur } & \text { Vegetasi } \\ \text { Mangrove. Hasil pengamatan vegetasi }\end{array}$ mangrove ditemukan 2 jenis mangrove yang tumbuh di Hutan Mangrove Desa Penunggul yaitu Rhizophora sp dan Avicennia sp. Kerapatan relatif suatu jenis (KR), Frekuensi relatif suatu jenis (FR), Dominansi relatif suatu jenis (DR), Indeks Nilai Penting (INP) vegetasi mangrove pada setiap stasiun tersaji dalam tabel Hasil analisis vegetasi mangrove tersaji dalam Tabel 1. 
Tabel 1. Kerapatan relatif suatu jenis (KR), Frekuensi relatif suatu jenis (FR), Dominansi relatif suatu jenis (DR), Indeks Nilai Penting (INP) vegetasi mangrove.

Stasiun 1

\begin{tabular}{llcccc}
\hline \multicolumn{1}{c}{ Tingkat } & \multicolumn{1}{c}{ Jenis } & KR $(\%)$ & FR (\%) & DR (\%) & INP \\
\hline Pohon & Rhizophora $\mathrm{sp}$ & 97.44 & 66.67 & 64 & 228.11 \\
& Avicennia $\mathrm{sp}$ & 2.56 & 33.33 & 36 & 71.89 \\
\multirow{3}{*}{ Pancang } & Rhizophora $\mathrm{sp}$ & 27.27 & 50.00 & & 77.27 \\
& Avicennia $\mathrm{sp}$ & 72.73 & 50.00 & & 122.73 \\
\multirow{5}{*}{ Semai } & Rhizophora $\mathrm{sp}$ & 26.67 & 50.00 & & 76.67 \\
& Avicennia $\mathrm{sp}$ & 83.33 & 50.00 & & 133.33 \\
\hline \multirow{2}{*}{ Stasiun 2} & & & & & \\
\hline Pohon & Rhizophora $\mathrm{sp}$ & 76.92 & 66.67 & 49 & 192.59 \\
& Avicennia $\mathrm{sp}$ & 5.13 & 33.33 & 25 & 63.46 \\
Pancang & Rhizophora $\mathrm{sp}$ & 54.55 & 50.00 & & 104.55 \\
& Avicennia $\mathrm{sp}$ & 9.09 & 50.00 & & 59.09 \\
Semai & Rhizophora $\mathrm{sp}$ & & & & \\
& Avicennia $\mathrm{sp}$ & 150.00 & 100.00 & & 250.00 \\
\hline
\end{tabular}

Sumber: Hasil Penelitian, 2012.

Dari Hasil pengamatan dijumpai 2 jenis vegetasi yang tersebar baik pada tingkat semai, pancang, maupun tingkat pohon yaitu api-api (Avicennia sp) dan bakau (Rhizophora sp). Berdasarkan hasil analisis vegetasi, pada stasiun 1, nilai INP pada tingkat pohon yaitu Rhizophora sp sebesar 228.11 dan Avicennia sp 71.89. Sedangkan pada tingkat pancang dan semai jenis Avicennia sp memiliki nilai INP yang lebih besar. Pada tingkat pancang nilai INP jenis Avicennia sp sebesar 122.73 dan Rhizophora sp sebesar 77.27. Pada tingkat semai nilai INP jenis Avicennia sp sebesar 133.33 dan Rhizophora sp sebesar 76.67. Mangrove pada tahap pertumbuhan pohon memperlihatkan adanya INP jenis Rhizophora sp. terkategori tinggi (> 152,07\%) dan Avicennia sp terkategori rendah $(<76,037 \%)$, nilai INP ini mengindikasikan hutan mangrove didominasi oleh Rhizopora sp.

Pada stasiun 2, nilai INP pada tingkat pohon yaitu Rhizophora sp sebesar 192.59 dan Avicennia sp 63.46. Pada tingkat pancang nilai INP jenis Rhizophora sp sebesar 104.55 dan Avicennia sp sebesar 59.09. Pada tingkat semai hanya jenis Avicennia sp dengan nilai INP sebesar 250. Mangrove pada tahap pertumbuhan pohon memperlihatkan adanya INP jenis Rhizophora sp. terkategori tinggi (> 128,39\%) dan Avicennia sp terkategori rendah $(<64,197$
$\%$, nilai INP ini mengindikasikan hutan mangrove didominasi oleh Rhizopora sp.

Analisis vegetasi mangrove memperlihatkan Indeks Nilai Penting (INP) tiap tingkatan yaitu tingkatan pohon, pancang dan semai memiliki nilai berbeda-beda. Hal ini menggambarkan pengaruh suatu jenis dalam komunitas mangrove yang dapat disebabkan oleh kerapatan, frekuensi atau besar kecilnya dominansi vegetasi mangrove. Menurut Suryawan (2007) jenis-jenis yang memperoleh INP tinggi berarti lebih menguasai habitatnya. Hutan mangrove Desa Penunggul dengan jenis Rhizophora sp lebih tinggi kerapatan, frekuensi dan dominansinya. Jenis ini disamping merupakan hasil penanaman juga memiliki keunggulan dalam menyesuaikan diri dengan kondisi lingkungan setempat.

\section{Manfaat Langsung Ekosistem Hutan Mangrove Desa Penunggul}

Hutan Mangrove Desa Penunggul memberikan manfaat baik secara ekonomi maupun ekologi. Menurut Harahab (2011) mangrove merupakan sumberdaya alam yang mempunyai fungsi dan manfaat ganda, yaitu ekonomis dan ekologis. Berdasarkan hasil penelitian, pemanfaatan hutan mangrove Desa Penunggul yaitu: berupa bibit mangrove, kegiatan perikanan yang menjadi sumber mata pencaharian masyarakat sekitar dari 
penangkapan kerang, kepiting, dan rajungan, serta pemanfaatan untuk pendidikan dan pariwisata.

\section{Bibit mangrove}

Bibit mangrove sangat diperlukan dalam usaha penyemaian dan penanaman mangrove sehingga memiliki nilai ekonomis penting. Penanaman mangrove merupakan salah satu usaha merehabilitasi dan mengembalikan sabuk hijau mangrove di pesisir pantai. Desa Penunggul merupakan daerah yang cukup berhasil dalam usaha penanaman mangrove, dan hingga kini masyarakat terus melakukan usaha penanaman baik secara swadaya maupun dengan bantuan pemerintah dan swasta. Bahkan, bibit mangrove Desa Penunggul kini tidak saja untuk memenuhi kebutuhan penanaman di Desa Penunggul dan Pesisir Kecamatan Nguling saja, namun permintaan juga datang dari daerah-daerah lain seperti Kabupaten Situbondo dan Kabupaten dan Kota Pasuruan.

Mangrove di Desa Penunggul yang banyak dibibitkan dari jenis bakau (Rhizophora sp). Jenis ini pula yang mendominasi hutan mangrove Desa Penunggul. Menurut Saparinto (2007) Rhizophora mucronata memiliki tipe benih vivipar dan bentuk benih yang dikumpulkan atau di ambil berupa propagul (bentuk biji panjang). Benih bibit didapatkan dengan cara mengambil buah/biji atau propagul (Rhizophora mucronata) yang masih di pohon maupun mengumpulkan dari yang jatuh di hutan mangrove.

Usaha pembibitan yang ada di Desa Penunggul kemudian melakukan penyemaian benih tersebut sampai menjadi bibit siap tanam. Proses pembibitan dilakukan selama kurang lebih 6 bulan. Pengambilan benih bibit dilakukan setiap hari dengan tangan atau ada pula yang menggunakan "weteng" sejenis alat yang terbuat dari bambu dengan panjang 2-3 meter dan terdapat pengait di ujungnya.

\section{Perikanan}

Kegiatan perikanan di hutan mangrove banyak dilakukan oleh masyarakat sekitar bahkan menurut hasil wawancara dengan tokoh Desa Penunggul, kegiatan pemanfaatan di hutan mangrove awalnya dilakukan oleh masyarakat luar Desa Penunggul. Masyarakat sekitar biasanya menggunakan sepeda atau dengan berjalan kaki untuk menuju hutan mangrove. Fenomena banyaknya masyarakat yang melakukan aktivitas kegiatan perikanan di hutan mangrove Desa Penunggul menunjukkan dampak positif dari keberhasilan penanaman dengan semakin luasnya hutan mangrove Desa Penunggul. Ikan yang menggunakan mangrove sebagai habitat tetap relatif terbatas, namun sejumlah besar ikan dan spesies laut menggunakan mangrove sebagai tempat berkembangbiak dan membesarkan anak. Ikanikan ini banyak ditangkap nelayan di tepian pantai maupun di lepas pantai dengan nilai ekonomi tinggi (Setyawan dan Kusumo, 2006). Adapun kegiatan perikanan di sekitar hutan mangrove Desa Penunggul yang dilakukan masyarakat yaitu penangkapan kepiting, kerang dan rajungan.

\section{a.Kerang}

Tipe tanah areal hutan mangrove yang berlumpur merupakan tempat hidup yang sesuai bagi berbagai jenis kerang (Ramadhan dan Savitri, 2007). Penangkapan kerang dilakukan di areal hutan mangrove dan lumpur tanah oloran yang membentang ke arah laut. Penangkapan dilakukan setiap hari dengan menggunakan tangan dan kantung berjaring sebagai tempat penampung hasil tangkapan. Disamping itu, ada pula yang menggunakan alat berupa arit untuk mengorek kerang dari lumpur.

Penangkapan biasa dilakukan pada pagi hari saat air surut. Berdasarkan hasil wawancara dan observasi, banyaknya masyarakat yang menangkap kerang disamping keberadaannya yang melimpah juga dikarenakan mudah, bisa cukup dengan tangan dan wadah untuk membersihkan. Penangkapan kerang juga dilakukan tidak saja oleh kaum pria tetapi juga oleh kaum perempuan. Kaum perempuan yang turut mencari kerang untuk dijual sebagai tambahan pengasilan bagi keluarga.

\section{b.Kepiting}

Kepiting merupakan salah satu biota yang hidup pada hutan mangrove dan bersubstrat berpasir dan berlumpur seperti hutan mangrove Desa Penunggul. Penelitian Pratiwi (2009) di Mangrove Delta Mahakam Kalimantan Timur menyebutkan bahwa krustasea/kepiting merupakan salah satu hewan benthos disamping moluska yang memakan bahan tersuspensi (filter feeder) dan umumnya sangat dominan pada substrat berpasir serta berlumpur. Jenis yang ditemukan merupakan jenis kepiting yang biasa hidup di daerah pasang 
surut dan termasuk ke dalam kategori pemakan serasah mangrove dan daun mangrove segar.

Kepiting juga merupakan biota yang memiliki nilai ekonomis penting. Penangkapan kepiting di hutan mangrove Desa Penunggul dengan frekuensi penangkapan setiap hari dan masih dilakukan secara terbatas dikarenakan masih sedikitnya orang yang melakukannya. Alat yang digunakan berupa jaring perangkap yang diberi umpan berbau menyengat seperti ikan asin yang dapat mengundang kepiting untuk keluar dari lubang sarangnya. Alat ini dipasang di dekat lubang-lubang tanah yang menjadi sarang kepiting di dalam hutan mangrove saat surut, dengan diberi penanda untuk memudahkan nelayan saat mengambilnya kembali. Saat air mulai pasang, perangkap yang dipasang tersebut di angkat. Ada pula alat yang menggunakan tongkat pengait dan tangan, penangkapan kepiting ini dilakukan saat air surut dengan langsung mencari di lubanglubang tanah yang menjadi sarang kepiting.

\section{c.Rajungan}

Penangkapan rajungan dilakukan dengan menggunakan jaring dengan perahu bermesin. Biasanya jaring dipasang pada siang hari dan diambil pada malam hari.. Untuk melaut membutuhkan 1 liter bahan bakar. Dalam kegiatan penangkapan rajungan, biaya operasional yang harus dikeluarkan per satu kali penangkapan berkisar Rp. 10.000-20.000 yang dipergunakan untuk biaya bahan bakar dan perbekalan. Selain dari biaya melaut, terdapat juga untuk perbaikan jaring dan mesin. Jaring ini menurut para nelayan secara rutin harus diganti karena setiap 10-14 hari biasanya mengalami kerusakan. Penangkapan rajungan dilakukan setiap hari, namun saat musim angin timur (silabung) biasanya para nelayan tidak melaut karena laut berombak besar. Jumlah tangkapan persatu kali penangkapan mencapai $3-5 \mathrm{~kg}$. dengan harga 25 ribu per $\mathrm{kg}$.

\section{Pendidikan dan Pariwisata}

Manfaat hutan mangrove Desa Penunggul lainnya adalah sebagai tempat pendidikan dan pariwisata. Beberapa perguruan tinggi dan sekolah telah datang baik untuk riset maupun belajar di hutan mangrove Desa Penunggul seperti Universitas Brawijaya Malang, Universitas Gajah Mada Yogyakarta, dan Institut Tekonologi Surabaya. Manfaat hutan mangrove Desa Penunggul sebagai daerah pariwisata masih terlihat permulaan. Hasil observasi dan wawancara dengan beberapa pihak baik tokoh masyarakat maupun instansi terkait, belum ada kesamaan pandangan terkait pengembangan hutan mangrove Desa Penunggul untuk menjadi tempat wisata. Meskipun dilapangan terlihat pembangunan fasilitas dan akses jalan mulai dibangun, namun belum ada perencanaan yang jelas terutama terkait pengembangan wisata mangrove yang mendukung keunikan hutan mangrove Desa Penunggul yaitu sebagai sebuah kawasan hutan yang berhasil dalam reboisasi dan tempat pembelajaran dalam pelestarian lingkungan. Pembangunan fasilitas yang baru saja dibangun belum semuanya terkomunikasikan dengan baik kepada masyarakat. Keunggulan keberadaan hutan mangrove Desa Penunggul dengan kondisi alam yang rimbun dan lokasi yang sangat tenang jauh dari keramaian sebenarnya menjadi daya tarik tersendiri bagi masyarakat sekitar maupun luar daerah dan bahkan luar negeri terutama dalam pendidikan dan konservasi lingkungan.

Pengunjung yang beriwisata masih didominasi masyarakat sekitar terutama para remaja yang biasanya mengabiskan waktu pulang sekolah atau akhir pekan. Informasi tentang keberadaan Hutan Mangrove Desa Penunggul pada umumnya berasal dari pengunjung yang pernah datang, meskipun saat penelitian baru saja dipasang gerbang wisata mangrove di jalan masuk Desa Penunggul dan pengunjung pun belum dikenakan biaya untuk memasuki kawasan hutan.

Manfaat langsung yang diidentifikasi di atas menunjukkan ekosistem hutan mangrove Desa Penunggul memiliki peran strategis bagi masyarakat sehingga hutan mangrove yang merupakan hasil kerja keras penyelamatan lingkungan oleh masyarakat perlu terus dijaga dan dilestarikan secara berkelanjutan.

\section{Kesimpulan}

Kondisi hutan mangrove Desa Penunggul memiliki vegetasi dari jenis api-api (Avicennia sp) dan bakau (Rhizophora sp). Pada stasiun 1 nilai INP pada tingkat pohon yaitu Rhizophora sp sebesar 228.11 dan Avicennia sp 71.89. Sedangkan pada tingkat pancang dan semai jenis Avicennia sp memiliki nilai INP yang lebih besar. Pada tingkat pancang nilai INP jenis Avicennia sp sebesar 122.73 dan Rhizophora sp sebesar 77.27. Pada tingkat semai nilai INP jenis Avicennia sp sebesar 
133.33 dan Rhizophora sp sebesar 76.67. Mangrove pada tahap pertumbuhan pohon memperlihatkan adanya INP jenis Rhizophora sp. terkategori tinggi (> 152,07\%) dan Avicennia sp terkategori rendah $(<76,037 \%)$, nilai INP ini mengindikasikan hutan mangrove didominasi oleh Rhizopora sp. Pada stasiun 2 nilai INP pada tingkat pohon yaitu Rhizophora sp sebesar 192.59 dan Avicennia sp 63.46. Pada tingkat pancang nilai INP jenis Rhizophora sp sebesar 104.55 dan Avicennia sp sebesar 59.09. Pada tingkat semai hanya jenis Avicennia sp dengan nilai INP sebesar 250. Mangrove pada tahap pertumbuhan pohon memperlihatkan adanya INP jenis Rhizophora sp. terkategori tinggi (> 128,39 \%) dan Avicennia sp terkategori rendah $(<64,197 \%)$, nilai INP ini mengindikasikan hutan mangrove didominasi oleh Rhizopora sp.

Pemanfaatan Ekosistem Hutan Mangrove Desa Penunggul berupa bibit mangrove, kegiatan perikanan yang menjadi sumber mata pencaharian masyarakat sekitar yaitu penangkapan kerang, kepiting, dan rajungan, serta pemanfaatan untuk pendidikan dan pariwisata.

\section{Daftar Pustaka}

Al Qardhawi Y. 2001. Islam Agama Ramah Lingkungan. Jakarta:Pustaka Al Kautsar.

Departemen Kelautan Dan Perikanan Jakarta. 2006. Strategi Pembangunan Kelautan Dan Perikanan Tahun 2007

Fauzi, A. 2005. Kebijakan Perikanan Dan Kelautan. Isu, Sintesis, Dan Gagasan. PT Gramedia Pustaka Utama. Jakarta.

Gunarto, 2004. Konservasi Mangrove Sebagai Pendukung Sumber Hayati Perikanan Pantai . Jurnal Litbang Pertanian, 23(1), 2004

Harahab,N. 2009. Pengaruh Ekosistem Hutan Mangrove Terhadap Produksi Perikanan Tangkap (Studi Kasus di Kabupaten Pasuruan Jawa Timur). Jurnal Perikanan (J.Fish. Sci.) XI (1) : 124-132

2010. Penilaian Ekonomi Ekosistem Hutan Mangrove dan Aplikasinya dalam Perencanaan Wilayah Pesisir. Graha Ilmu. Yogyakarta 2011. Analisis Ekonomi-Ekologi Hutan Mangrove Dan Alternatif Pemanfaatan
http://www.scribd.com/doc/57262909/A nalisis-Ekonomi-ekologi-HutanMangrove-Dan-Alter-Nat-If. akses tanggal 4 Juli 2011

2011. Valuasi Ekonomi Ekosistem Hutan Mangrove Dalam Perencanaan Wilayah Pesisir. Berk. Penel. Hayati Edisi Khusus: 7A (59-67), 2011

Karminarsih. 2007. Pemanfaatan Ekosistem Mangrove bagi Minimasi Dampak Bencana di Wilayah Pesisir JMHT Vol. XIII (3): 182-187, Desember 2007 ISSN: 0215-157X.

Keputusan Menteri Negara Lingkungan Hidup No.201 Tahun 2004 Tentang Kriteria Baku Dan Pedoman Penentuan kerusakan Mangrove.

Kompas, 21 Desember 2011. 4,1 Juta Hektar Hutan Bakau Rusak

Kusmana, 2009. Pengelolaan Sistem Mangrove Secara Terpadu. Workshop Pengelolaan Ekosistem Mangrove di Jawa Barat, di Hotel Khatulistiwa - Jatinangor, 18 Agustus 2009

Mahmudi, M. 2011. Analisis Daya Dukung Ekosistem Mangrove Terhadap Produksi Ikan di Kawasan Reboisasi Rhizophora Wilayah Kecamatan Nguling Kabupaten Pasuruan. Disertasi. Program Pasca Sarjana Fakultas Pertanian Universitas Brawijaya Malang.

Mukarim, 2012. Paparan pada Seminar dan Lokakarya Nasional Perairan 2012. Universitas Brawijaya Malang, 19-20 Januari 2012

Muliawan dan Priyatna, 2008. Valuasi Ekonomi Sumberdaya Danau Tempe, Kabupaten Wajo, Propinsi Sulawesi Selatan: Nilai Bukan Manfaat J. Bijak dan Riset Sosek KP. Vol.3 No.1, 2008

Murdiyanto, B. 2003. Mengenal, Memelihara dan Melestarikan Ekosistem Hutan Bakau. Direktorat Jendral Perikanan Tangkap Departemen Kelautan dan Perikanan. Jakarta

Nazir, M . 2005. Metode Penelitian. Penerbit Ghalia Indonesia (cetakan keenam). Bogor

Onrizal. 2008. Teknik survey dan analisa data sumberdaya mangrove. Pelatihan Pengelolaan Hutan Mangrove Berkelanjutan untuk Petugas/Penyuluh Kehutanan di Tanjung Pinang, 14-18 Maret 2008 
Penyusunan Perencanaan dan Pengelolaan Kawasan Pesisir Kabupaten Pasuruan, 2009. Bappeda Kabupaten Pasuruan Jawa Timur

Pratiwi,R. 2009. Komposisi Keberadaan Krustasea Di Mangrove Delta Mahakam Kalimantan Timur. Makara, Sains, Vol. 13, No. 1, April 2009: 65-76

Rahman. 2008. Koefisien Seret Gaya Gelombang Pada Apo Dengan Tambahan Gedhek. Media Teknik Sipil/ Juli 2008

Ramadhan dan Savitri. 2007. Identifikasi Jenis Dan Nilai Pemanfaatan Sumberdaya Mangrove Di Teluk Kupang, Propinsi Nusa Tenggara Timur. J. Bijak dan Riset Sosek KP. Vol.2 No.2

Rencana Strategis Badan Lingkungan Hidup Provinsi Jawa Timur Tahun 2010 2014)

Rusila Noor, Y., M. Khazali, dan I N.N. Suryadiputra. 2006. Panduan Pengenalan Mangrove di Indonesia. PHKA/WI-IP, Bogor. (cetakan ke-2)

Saparinto, C.2007. Pendayagunaan Ekosistem Mangrove. Penerbit Dahara Prize. Semarang

Setyawan dan Kusumo, 2006. Pemanfaatan Langsung Ekosistem Mangrove di Jawa Tengah dan Penggunaan Lahan di Sekitarnya; Kerusakan dan Upaya Restorasinya. BIODIVERSITAS. ISSN: 1412-033X Volume 7, Nomor 3 Juli 2006 Halaman: 282-291

Setyawan, A D, Ari Susilowati, Wiryanto. 2002. Habitat Reliks Vegetasi Mangrove Di Pantai Selatan Jawa. B I O D I V E R S I T A S Volume 3, Nomor 2

Suryawan. 2007. Keanekaragaman Vegetasi Mangrove Pasca Tsunami Di Kawasan Pesisir Pantai Timur Nangroe Aceh Darussalam. BIODIVERSITAS. ISSN: 1412-033X Volume 8, Nomor 4 Oktober 2007. Halaman: 262-265

Suwargana, N. 2008. analisis Perubahan Hutan Mangrove Menggunakan Data Penginderaan Jauh Di Pantai Bahagia, Muara Gembong, Bekasi. Jurnal Penginderaan Jauh Vol. 5, 2008 :64-74

www.pasuruankab.go.id. Di akses tanggal 21 Desember 2011 